To cite: I Kajiru \& JC Mubangizi 'Human rights violations of persons with albinism in Tanzania: The case of children in temporary holding shelter' (2019) 19 African Human Rights Law Journal 246-266 http://dx.doi.org/10.17159/1996-2096/2019/v19n1a12

\title{
Human rights violations of persons with albinism in Tanzania: The case of children in temporary holding shelters
}

\section{Ines Kajiru*}

Post-doctoral Fellow, School of Applied Human Sciences, University of KwaZulu-Natal, South Africa

https://orcid.org/0000-0002-1919-1148

\section{John C Mubangizi**}

Professor and Dean, Faculty of Law, University of the Free State, South Africa https://orcid.org/0000-0002-1408-268X

\section{Summary}

Albinism is a genetic condition that occurs in people of all races and in all parts of the world. In Tanzania, and in many other places where it occurs, children living with albinism constantly are subjected to discrimination, stigmatisation, persecution and ridicule. However, the most disturbing phenomenon is the mindless killing of these children. The threat of being murdered forces some of these children to flee from their homes and communities. In an attempt to address the situation and to protect these children, the Tanzanian government has established temporary holding shelters. This article explores the challenges faced by children at these temporary holding shelters and the extent to which their rights are violated. Despite Tanzania's ratification of the 1989 UN Convention on the Rights of the Child in 1991, which compels it to prevent violence against children and to uphold the right of all children to human dignity and physical integrity, human rights violations against these children abound. It is evident that the Tanzanian government's commitment to protect all children, as required by the Law of the Child Act, is lacking in implementation and effectiveness. The article utilises secondary data

\footnotetext{
* $\quad$ LLB LLM (Mzumbe) PhD (KwaZulu-Natal); ikajiru@gmail.com

** LLB (Makerere) LLM (Cape Town) LLD (KwaZulu-Natal); Mubangizijc@ufs.ac.za
} 
obtained through a review of relevant documents. The findings point to a lack of security, care and protection of the children in temporary holding shelters. It is concluded that the Tanzanian government needs to take effective and sustainable steps towards the elimination of all forms of violence against children, generally, and against children with albinism, in particular. The government also is urged to improve the conditions in these shelters in order to uphold the rights of the children residing there as provided for under international as well as domestic law.

Key words: human rights; albinism; children; discrimination; shelters

\section{Introduction}

Albinism is a condition that occurs due to the 'absence of pigmentation in the epidermis that normally gives colour to the skin, the hair and the irises of the eye'. 1 As a result, it 'may be accompanied by vision and eye problems and may ultimately lead to skin cancer'. ${ }^{2}$ Although albinism occurs in people of all races and in almost all parts of the world, it is more prevalent in certain regions than in others. Tanzania has the highest prevalence of albinism in Africa and it is estimated that one in every 2000 people suffers from this condition. ${ }^{3}$ Tanzania also has the 'highest reported levels of discrimination and violence against people with albinism on the African continent' ${ }^{\prime}{ }^{4}$

Historically, around the globe children with albinism faced appalling discrimination, stigmatisation and social exclusion that often culminated in physical attacks and killings. ${ }^{5}$ In the twenty-first century the killing of children with albinism for many years has continued almost unabatedly in Tanzania. ${ }^{6}$ This situation mainly is because society continues to believe that bearing a child with albinism is a curse. ${ }^{7}$ Moreover, persons with albinism are killed for ritual purposes as it is believed that the potions witchdoctors concoct from these people's body parts possess magical powers capable of bringing great

1 SA Kirk, J Gallagher \& NJ Anastasiow Educating exceptional children (2000) 54.

2 S Judith 'Albinism Gale Encyclopaedia of Children's Health: Infancy through adolescence' (2006), http://www.encyclopedia.com/topic/Albinism.aspx (accessed 20 January 2018).

3 Under the Same Sun (UTSS) 'The Tanzania Albino Society estimates that there are more than 150000 people with albinism in Tanzania' (2012) Assessment Report of Centres for PWA.

4 UTSS 'Attacks of persons with albinism' Report of 15 August 2013, where it is noted that 55 persons with albinism have been attacked, many of whom were mutilated.

5 J Paul 'Strategies to address vulnerable populations' (2012), http://hir.harvard. edu/strategies-to-address-vulnerable-populations?page=0,2 (accessed 12 February 2018).

6 AR King et al 'Facts about albinism: International Albinism Day' (2004), University of Minnesota, http://www.cbc.umn.edu/iac/facts.htm (accessed 14 January 2018).

7 As above. 
wealth and fame if consumed or rubbed onto the body. ${ }^{8}$ It has been reported that witchdoctors have a preference for the use of children's body parts as children are believed to be innocent and pure. Therefore, potions made from the body parts of children with albinism generally are deemed more potent in producing the desired results. ${ }^{9}$

The threat of being killed has compelled many persons with albinism to flee from their homes and communities, becoming internally-displaced persons (IDPs). ${ }^{10}$ IDPs are defined as 'persons forcibly uprooted from their homes by violent conflicts, gross violations of human rights and other traumatic events but who remain within the borders of their own countries'.11 This definition adequately describes persons with albinism who, since the killings increased in 2007 and 2008 in Tanzania, have had to flee their homes to seek sanctuary in places with better security - real and perceived. ${ }^{12}$ Children with albinism are placed in these centres, known as temporary holding shelters, either by government intervention or through the initiatives of individuals. ${ }^{13}$

The discussion in the article focuses on the violation of the human rights of children with albinism in temporary holding shelters. These rights include, but are not limited to, the right to security and protection, care and support; freedom from torture, inhuman and degrading treatment; the right against discrimination; the right to education; the right to health care; and the right to an adequate standard of living. First, however, it is important to understand the contextual background to the existence of temporary holding centres in Tanzania.

\section{Temporary holding shelters in Tanzania}

As a wave of ritual killings and amputations of persons with albinism, especially children, began to spread in Tanzania in 2007, the government initiated measures designed to ensure the physical safety of children with albinism. One such measure was to issue a provisional emergency response to the surge of attacks by establishing so-called temporary holding shelters where children with albinism could be housed for their protection.

8 UTSS 'Children with albinism in Africa: Murder, mutilation and violence' (2013), http://www.underthesamesun.com/aboututss (accessed 14 January 2018).

9 As above.

10 As above.

11 SV de Mello 'Guiding principles on internal displacement', https://www.un.org/ ruleoflaw/files/guiding_principles[1].doc (accessed 14 January 2018).

12 UTSS 'Children with albinism: Violence and displacement' Report submitted to the UN Committee on the Rights of the Child 2014, https://tbinternet.ohchr.org/ Treaties/CRC/Shared\%20Documents/TZA/INT_CRC_NGO_TZA_18032_E.pdf (accessed 14 January 2018).

13 As above. 
Generally, existing boarding schools were converted into these 'holding shelters', particularly in the Lake Zone region that is situated in North-Western Tanzania. ${ }^{14}$ These boarding schools initially had been designated by the government for children with various disabilities or conditions warranting some level of special care. ${ }^{15}$ For example, Buhangija in Shinyanga was a boarding school for children with hearing and visual impediments, but in 2009 the government converted it into a temporary holding shelter for children with albinism. ${ }^{16}$ Mitindo boarding school also was converted into a centre for persons with albinism. ${ }^{17}$ This step was taken in 2007 when various reports about the killing of persons with albinism became public knowledge. ${ }^{18}$

It should be pointed out that these schools had not been designed to accommodate the large number of children with albinism that fled from their homes in fear of their lives. A report by the Independent Expert on the Enjoyment of Human Rights by Persons with Albinism indicated that there were more than 32 known schools and other facilities that were converted into shelters in the country. ${ }^{19}$ However, information presented and discussed in this article pertains to only nine centres that are located in the Lake Zone region of NorthWestern Tanzania which is notorious for the atrocities committed against persons with albinism, especially children. A number of killings of albino children have also been reported in this region. ${ }^{20}$ The centres are Mugeza Bukoba Rural in Kagera; Kabanga Kasulu in Kigoma; Buhangija Shinyanga Urban in Shinyanga; Furaha Tabora Urban in Tabora; Pongwe Tanga in Tanga; Mitindo in Mwanza; Kitengule Karagwe in Kagera; Bukumbi Misungwi in Mwanza; and Missionaries of Charity Tabora in Tabora. 21

14 African Committee of Experts on the Rights and Welfare of the Child (African Children's Committee) Report on Investigative Mission on the Situation of Children with Albinism in Temporary Holding Shelters - Tanzania (2016), http:// globaldisability.org/wp-content/uploads/2016/01/Report-on-the-Investigative_Mis sion_on_the_Situation_of_Children_with_Albinism_ACERWC-March-2016.pdf (accessed 5 April 2019).

15 UTSS Report (n 12).

16 Human Rights Watch '"It felt like a punishment"': Growing up with albinism in Tanzania' (2017), https://www.hrw.org/news/2019/02/09/it-felt-punishmentgrowing-albinism-tanzania (accessed 1 April 2019).

17 UTSS Report (n 12).

18 UNICEF/UTSS 'Situation assessment of the centres of displaced persons with albinism in the Lake Zone and Tanga Regions: Findings From Under The Same Survey' (2012), http://www.underthesamesun.com/resources (accessed 5 April 2019).

19 Human Rights Council 'Report of the Independent Expert on the enjoyment of human rights by persons with albinism on her mission to the United Republic of Tanzania' (2018), https://reliefweb.int/report/united-republic-tanzania/reportindependent-expert-enjoyment-human-rights-persons-albinism (accessed 2 April 2019).

20 African Children's Committee Report (n 14).

21 Human Rights Council (n 19). See also UTSS 'A report on situation assessment of the centres of displaced persons with albinism in the Lake Zone and Tanga Regions' (2014) 54. 
Ordinarily, children with albinism were brought to the shelters through government directives to district and community leaders to bring them in, whereas other children were referred through individual initiatives. ${ }^{22}$ Individual initiatives also resulted in the relocation of children with albinism to urban centres where their lives were not as much at risk. ${ }^{23}$ Government orders to protect persons with albinism had to be enforced by district commissioners, who were mandated to oversee the security of these persons in their respective districts. ${ }^{24}$ Local leaders simply responded to orders from the district commissioner that all children with albinism from their respective areas must be relocated to the temporary holding shelters. Should anything happen to any of these children, the district commissioners would be held responsible. ${ }^{25}$ Unfortunately, this initiative meant that children had to be removed from their homes and families by government officials with or without any consultation or consent, and placed in shelters where they effectively were isolated from society and their families. ${ }^{26}$

A matter of concern is that there were no designed procedures through which the children were to be removed and admitted to these centres. ${ }^{27}$ In some cases children were forcibly taken by police officers from parents who were reluctant to release them, whereas others were picked up at bus stands without their parents' knowledge. ${ }^{28}$ These 'temporary holding' shelters became akin to orphanages as some parents took advantage of the opportunity to abandon their children if they did not want them due to societal prejudice and rejection. ${ }^{29}$ Many children with albinism have been abandoned in these centres for years without any contact with their parents.

In terms of ownership some of the centres are managed under the auspices of the government, particularly the Ministry of Education and Vocational Training, the Ministry of Health and Social Welfare, and District or Municipal Councils, while others are owned by faith-based organisations. ${ }^{30}$ Some shelters thus are government sponsored while others are sponsored by non-governmental organisations (NGOs)

22 UNICEF/UTSS (n 18).

23 As above.

24 African Children's Committee Report (n 14).

25 As above.

26 UTSS Report (n 12).

27 Human Rights Watch (n 16).

28 Tanzania Albino Society 'An island refuge for Tanzania albino people' (2016) https://www.pri.org/stories/2016-06-20/island-refuge-tanzanias-albino-people (accessed 2 April 2019).

29 UTSS Report (n 12).

30 UNICEF and UTSS 'Sexual abuse cases reported in assessed schools and centres hosting internally displaced children with albinism and other children with disabilities' (2011) Report to the Ministry of Education and Vocational Training (MoEVT), https://www.underthesamesun.com/sites/default/files/Centres\%20Hol ding\%20Displaced\%20PWA\%20-\%20A\%20Report\%20from\%20Tanzania\%20-\% 202012.pdf (accessed 2 April 2019)._ 
such as the Missionaries of Charity in Tabora. ${ }^{31}$ Under the Same Sun (UTSS) has played an important role in sponsoring hundreds of children of all ages residing in these shelters. ${ }^{32}$ A noteworthy initiative is that UTSS and other NGOs financially support the production of sun cream, the first initiative of its kind in this country. ${ }^{33}$ The cream, known as 'KiliSun', which helps to protect persons with albinism against the sun's rays, is distributed to all the centres. ${ }^{34}$ Moreover, UTSS has accepted its education advancement mandate by sponsoring 66 students with albinism on its education scholarship programme. $^{35}$

\section{Legal framework for the rights of children with albinism in Tanzania}

The concept of human rights was devised as an umbrella concept for the protection of people from discriminatory and oppressive state policies. ${ }^{36}$ The Universal Declaration of Human Rights, 1948 (Universal Declaration) ${ }^{37}$ establishes a basic human rights principle that 'all human beings are born free and equal in dignity and rights'. ${ }^{38}$ Moreover, vulnerable groups such as women, indigenous people and children have been assigned special protection by the United Nations (UN) legal framework, with the obligation on governments to domesticate these provisions in their local laws.

The protection of children's rights under international law can be traced back to the first Declaration of the Rights of the Child that was adopted by the League of Nations in 1924. This was a brief document containing only five principles that guided member states in terms of child welfare. An extended version of this text was adopted by the UN General Assembly in 1948, which was followed by a revised version that was adopted by the General Assembly in 1959 as the UN Declaration on the Rights of the Child. However, the Declaration was not binding as an international treaty. ${ }^{39}$ In 1978 a proposal for a new convention on children's rights was submitted by Poland to be

\footnotetext{
31 As above.

32 Human Rights Watch (n 16).

33 African Children's Committee Report (n 14).

34 As above.

35 As above.

36 MA Glendon 'The rule of law in the Universal Declaration of Human Rights' (2004) 2 Northwestern Journal of International Human Rights 4.

37 Adopted by General Assembly Resolution 217 A (III) of 10 December 1948.

38 Art 1 Universal Declaration of Human Rights (1948).

39 S Bourne 'Children's rights: A brief introduction to the history and principles of the United Nations Convention on the Rights of Child' (2017), https://www.linked in.com/pulse/childrens-rights-brief-introduction-history-united-nations-bourne (accessed 13 February 2018).
} 
adopted in 1979. However, this proposal was not adopted before 1989 due to consistent constraints and issues. ${ }^{40}$ The Convention on the Rights of the Child (CRC) of $1989^{41}$ was based on Poland's draft proposal, with some amendments. In essence it was recognised by all signatories that the 1959 Declaration on the Rights of the Child did not adequately reflect the needs of many of the world's children. ${ }^{42}$ This gap was addressed by the $\mathrm{CRC}^{43}$ and, in Africa, by the 1990 African Charter on the Rights and Welfare of the Child (African Children's Charter). ${ }^{44}$ Both instruments emphasise the best interests of the child.

Article 4 of CRC makes it mandatory for governments to take every available measure to protect and respect children's rights. States that ratified the Convention thus agreed to take every step in reviewing their laws relating to children. CRC also includes processes for assessing states' legal, social and economic services as well as their educational and health systems. However, every government is responsible for taking basic action and for guaranteeing that the minimum values and primary rules of the Convention are met. ${ }^{45}$ It is thus the duty of every state to create a bedrock environment while ensuring that its children's rights are protected so that they are enabled to grow in order to achieve their prospective goals as worthy citizens. In accomplishing this obligation new laws may have to be enacted or inadequate laws may have to be amended.

On the African regional level the African Children's Charter emphasises that a child's best interests are paramount in every aspect of human behaviour. ${ }^{46}$ At the national level, the Bill of Rights, which is entrenched in the Constitution of the United Republic of Tanzania of 1977, enshrines equality as the principle for all and prohibits discrimination on all grounds. The Constitution guarantees and protects human rights in all aspects of human life. It is important at this point to note that the founding values of the Constitution, namely, human dignity, equality, freedom, privacy and security, 47 also include freedom from any form of discrimination. The Constitution also provides for the right to freedom, privacy and

40 As above.

41 General Assembly Resolution 44/25 of 20 November 1989.

42 As above.

43 Art 3 of the UN Convention on the Rights of the Child (CRC), adopted by Resolution $44 / 25$ of the UNGA on 20 November 1989; entered into force 2 September 1990.

44 Art 4 of the African Charter on the Rights and Welfare of the Child, adopted by the Assembly of Heads of State and Government in 1990; entered into force 29 November 1999.

45 K Abraham \& T Mathew Children rights manual: Handbook for parliaments (2011) 24.

46 Art 4 African Children's Charter, http://www1.umn.edu/humanrts/africa/afchild. htm (accessed 14 February 2018).

47 Arts $13(d), 15 \& 16$. 
personal security; the right to dignity 48 and the right not to be tortured in any way; and the right not to be treated or punished in a cruel, inhuman or degrading manner as indicated in article 13(6)(e) of the Constitution. This means that children with albinism have inherent rights, including the right to the protection of their human dignity.

Also, it is important to note that article 30(1) of the Tanzanian Constitution clearly states that no person should act in a manner that causes interference with or curtailment of the rights and freedoms of other persons or of the public interest. Clearly, discrimination on the basis of race, gender and any other factor is prohibited under the Tanzanian Bill of Rights. This determination implies that the interpretation of human rights provisions takes precedence over other legal rights as they are so broadly conceived and are located at the pinnacle of the protection of society. ${ }^{49}$ The interpretation of the Bill of Rights thus comprises overt value judgments that amount to acts of creation and imagination. ${ }^{50}$

Efforts to prevent violence should be part of a government's national commitment to uphold the rights of each individual and to protect his or her human dignity and physical integrity. This commitment is reflected in the Tanzania Law of the Child Act, $2009^{51}$ and the Persons with Disabilities Act. ${ }^{52}$ The Law of the Child Act incorporated all important elements of CRC, its Optional Protocols and other standards that were necessary to create a protective atmosphere for children. The Act defines a child as 'a person below the age of 18 years' ${ }^{53}$ Although the Act makes no specific mention of children with albinism, it is a milestone in the quest for upholding children's rights as it includes a structure for a child protection system that is intended 'to prevent and respond to violence, abuse, neglect and the exploitation of children' ${ }^{54}$ It also contains provisions regarding guardianship, custody, foster care or adoption, residential care, mental well-being, and access to essential services such as health care and education. ${ }^{55}$

Despite constitutional and legislative protection, between 2000 and 2017, 189 incidences of violence, including 76 murders, were

\section{Art 16.}

49 GT Baloyi 'When culture clashes with individuals' human rights: A practical theological reflection on the dignity of widows' (2017), http://www.scielo.org.za/ scielo.php?script=sci_arttext\&pid=\$2074-77052017000100013 (accessed 14 January 2018).

50 Matiso \& Others $v$ Commanding Officer, Port Elizabeth Prison \& Another 1994 (4) SA 592597.

51 Act 21 of 2009 .

52 Act 9 of 2010.

53 Secs 4(1)-(2) deal with the best interests of the child.

$54 \operatorname{Sec} 9(3)(a)$.

$55 \operatorname{Sec} 13(1)$. 
recorded involving persons with albinism as victims, and approximately 45 per cent of those killed were children. ${ }^{56}$ Based on the impact and implications of these events 'the government made financial and time-bound commitments to strengthen child protection through various national plans of action that would be regularly monitored'.57 Regulations and rules were drafted (the Child Protection Rules and Regulations, 2015) to operationalise the Law of the Child Act more effectively, but evidence points to the fact that implementation by some of the responsible departments is almost non-existent. ${ }^{58}$ It must be pointed out that this failure is not due largely to a lack of trying by government. For example, the Child Development Policy of 2008 is currently being revised to ensure that children are protected against violence, abuse and exploitation. The Law of the Child Act is expected strongly to complement and give legal force to the policy. Moreover, the second National Costed Plan of Action for Most Vulnerable Children 2013-2017 (NCPA II) provides an overarching framework to address child protection in Tanzania.

Section 4 of the Persons with Disabilities Act ${ }^{59}$ entails respect for human dignity, the freedom of individuals to make their own choices and the independence of persons with disabilities. This section also asserts non-discriminatory practices in every domain. However, it is the duty of the responsible Minister to take 'appropriate legislative and administrative measures ... with a view to achieving the full realisation of [the] rights of persons with disabilities as set out under the $\mathrm{Act}^{\prime}{ }^{60}$ In this regard the government is required to -

(a) ensure that all persons with disabilities are equal, and are fully entitled without any discrimination to the equal protection and benefits of this Act;

(b) prohibit all forms of discrimination on the basis of disability and guarantee the persons with disabilities equal and effective legal protection against discrimination on all grounds; and

(c) for purposes of promoting equality and elimination of all forms of discrimination, take all appropriate measures to ensure that reasonable changes are provided to persons with disabilities of all ages and gender. ${ }^{61}$

Despite all the advances in the legal framework regarding children's rights, there is clear evidence that the implementation of these rights does not occur at the same speed as the development of legislation and policies. This gap raises doubts as to whether legislation that

56 UNICEF Report 'Building a holistic child protection system, step by step, in the United Republic of Tanzania' (2015), https://www.unicef.org/protection/files/ Tanzania_CP_system_case_study.pdf. (accessed 6 April 2019).

57 As above.

58 As above.

59 Act 9 of 2010.

$60 \operatorname{Secs} 5(2),(3) \&(4)$ of the Act.

61 Sec 6 of the Act. This wording is similar to that used in the UN Convention on the Rights of Persons with Disabilities. 
governs children's rights and the agents that are mandated to implement this legislation really act in the best interests of the child, as paradoxical conditions seem to indicate otherwise.

\section{Violation of children's rights in temporary holding shelters}

\subsection{Discrimination and stigmatisation}

As shown above, there is no shortage of legal mechanisms at international, regional or national level for protecting the rights of children. With specific reference to discrimination, article 2 of $\mathrm{CRC}^{62}$ requires that all children be fairly and respectfully treated regardless of their race, gender or language. CRC explicitly imposes duties and responsibilities on parents and any other person who takes care of children to protect and preserve their rights. All care givers of children should ensure that their charges are protected from being physically or mentally harmed or mistreated. ${ }^{63}$ Moreover, it is the duty of the government to ensure proper care for and the protection of children from neglect, violence and abuse. ${ }^{64}$ Clearly, children with albinism, as does every other child, fall within the ambit of the law as provided above, regardless of any condition that makes them look different from other children. The provisions of CRC are at the heart of children's rights, categorically stating that all children are entitled to be free of any kind of discrimination and that all children are entitled to fair treatment.

At the domestic level, article 12 of the Tanzanian Constitution of provides:

(1) All human beings are born free and are all equal.

(2) Every person is entitled to recognition and respect for his/her dignity.

Article 13(4) articulates the principle of non-discrimination as follows: 'No person shall be discriminated against by any person or any authority acting under any law or in the discharge of the functions or business of any state office.'

Section 9(3)(a) of the Law of the Child Act protects children from discrimination, violence, abuse, neglect and any other act that exposes them to physical and moral hazards and oppression. Section 13(1) forbids any person from subjecting a child to torture or to any other cruel, inhuman punishment or degrading treatment, including any cultural practice that dehumanises or is injurious to the physical and mental well-being of a child.

62 General Assembly Resolution 44/25 of 20 November 1989.

63 Art 19 CRC.

64 As above. 
Whereas the protection of children against discrimination is guaranteed under national and international law, children with albinism in Tanzania, especially those residing in temporary holding shelters, continue to suffer discrimination on the basis of their skin colour and their distinctive features. ${ }^{65}$ One would expect that the rights of children with albinism in holding centres would be protected by the caregivers to whom they are entrusted. ${ }^{66}$ However, this expectation seems to be a fallacy as these children reportedly suffer severe discrimination at the hands of matrons, patrons, teachers and security guards who have no sympathy for them. ${ }^{67}$ According to Kajiru, discrimination against these children is a daily occurrence. ${ }^{68}$ As a consequence some of these children's self-confidence is destroyed, and they feel embarrassed and rejected with no opportunity to enjoy life as other children do. ${ }^{69}$ The plight of children with albinism raises the concern that Tanzania's commitment to CRC and the Law of the Child Act is mere lip service as the implementation of these instruments clearly is a problem.

\subsection{The right to security and safety}

Article 25 of CRC provides that children who are looked after by a person other than their parents have the right to security and a living environment that is safe and secure and has appropriate arrangements for comfort and sustenance. This provision means that their care and treatment should always be based on the principle of 'serving the best interests of the child'. ${ }^{70}$ As far as article 25 is concerned the Tanzanian government is obliged to ensure the security of every child living in a temporary holding shelter. It should be acknowledged that the government has accepted its responsibility in this regard, as the establishment of temporary holding shelters for the protection of this vulnerable group of children was a step in the right direction. However, grave concerns have been raised that the safety and security of a child with albinism is compromised in these centres, and that their situation seems to deteriorate rather than improve. ${ }^{71}$ A report by UNICEF/UTSS indicates that some centres have dilapidated doors while some doors have no locks. ${ }^{72}$ Mugezi was mentioned in this regard. It was also reported that some centres have no fences, making it easy for community members with nefarious

65 African Children's Committee Report (n 14).

66 I Kajiru 'The clash between harmful cultural beliefs and human rights: A case study of atrocities against people with albinism in Tanzania' PhD thesis, University of KwaZulu-Natal, 2018175.

$67 \quad$ Kajiru (n 66) 176.

68 As above.

69 As above.

70 TC Louie \& MS Gloudina 'The voice of the child: Experiences of children in middle childhood regarding Children's Court procedures' (2017) 53 Social Work Stellenbosch 5.

71 African Children's Committee Report (n 14).

72 As above. 
intentions to gain free access to the centre and endanger the lives of the children who are hunted for their body parts. ${ }^{73}$ The reason these children are moved to a shelter is to find a place where they will be safe from attacks and killings, yet easy access to the centres exposes them to dire threats. ${ }^{74}$ Moreover, security officers and guards reportedly are ineffectual and irresponsible and some of them are too old to manage the task. ${ }^{75}$ According to the UTSS report some security guards performed their duties while unarmed and some slept in their offices throughout the night. ${ }^{76}$ The African Children's Committee Report further added that these centres clearly are not conducive to maintaining these children's safety and security. ${ }^{77}$ For instance, the lack of electricity and water provision in some centres is a persistent problem. ${ }^{78}$ In some cases the children complained that they were 'forced to walk for long distances without an escort through bushes or forests to fetch water and firewood' ${ }^{79}$ All these children were afraid either of being attacked or bitten by snakes. The children in these centres are sent out to milk cows, cut grass for the cows, till the land and perform other tasks without physical protection. ${ }^{80}$ Therefore, they are constantly exposed to risk and insecurity in an environment where they should feel protected. ${ }^{81}$ Therefore, it is no wonder that many of these children are psychologically and emotionally disturbed and that they struggle to function as 'normal' children.

Despite the government's efforts in establishing these so-called temporary holding shelters for the purpose of protecting children with albinism from attacks and killings, the conditions in these centres are shocking as violations of children's rights sometimes occur more within these walls than outside. ${ }^{82}$ The report reveals that many centres have a dilapidated infrastructure with very few members of staff. Security measures also are inadequate. The children constantly are at risk of being attacked as no adequate safety measures have been put in place.

\subsection{The right to an adequate standard of living}

Article 25 of the Universal Declaration provides a general overview of the standard of living that is deemed adequate for the health and well-being of people, and includes 'medical care and [the] necessary social services'. Article 11 of the International Covenant on Economic, Social and Cultural Rights (ICESCR) contains similar provisions and

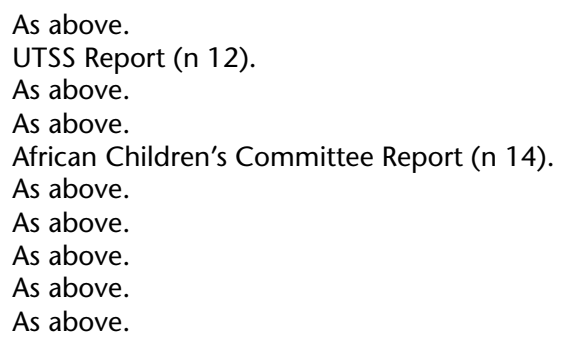


stipulates that '[e]veryone has the right to an adequate standard of living for himself and his family'. As far as children are concerned, this means that they are entitled to a standard of living that is good enough to meet their physical, mental and emotional needs. In this regard it is the duty of the government to ensure that children live in a secure environment, enjoy an adequate standard of living, are housed in sufficiently spacious conditions and live in a wholesome environment. The provision of an adequate standard of living depends on and is determined by the existence of the necessary facilities and infrastructure. However, available evidence points to the fact that little attention has been given to the development of quality infrastructure to accommodate children with albinism in state institutions. As a result, adequate health care and education are lacking in the temporary holding shelters where children with albinism are accommodated. ${ }^{83}$

Evidence also revealed the fact that even the dormitories where these children are housed are fraught with problems such as poor ventilation and insufficient beds and mattresses, as two to three children generally are obliged to share a bed or mattress. ${ }^{84}$ Poor sanitation, a limited number of toilets and a lack of security lighting also are problems that affect these children's lives, resulting in a violation of the right to health and an adequate standard of living. Overcrowding also is a factor, as the large number of children does not tally with the few personnel that have to care for them. ${ }^{85}$ Therefore, caregivers' responsibilities seem to outweigh their human capacity and capabilities, which is further exacerbated by financial constraints. It is in this context that workers' attitudes and their treatment of the children are characterised by obvious violations of these children's rights. Overcrowding leads also to severe health problems.

The right to an adequate standard of living entails the right to adequate and nutritious food, good quality health care, safe drinking water, a clean and safe environment, and information to help the children stay healthy. ${ }^{86}$ Many children in the shelters suffer from various stages of skin cancer, a high crime rate, discrimination, food shortages, malnutrition, a lack of resources such as appropriate reading materials, and vision impairments. ${ }^{87}$ The Tanzanian law on disability is broad enough to recognise persons with albinism as a group of persons with disabilities. ${ }^{88}$ The Persons with Disabilities Act is

\footnotetext{
83 African Children's Committee Report (n 14).

84 As above.

85 As above.

86 Art 24 CRC.

87 J Burke, TJ Kaijage \& JJ Langba 'Media analysis of albino killings in Tanzania: Social work and human rights perspective' (2014) 8 Ethics and Social Welfare 125.

88 V Marcon 'Albinism in Tanzania: A human rights issue: An experience of monitoring the "white blacks"' Master's dissertation, Università Degli Studi Di Padova, 201440.
} 
the primary legal instrument in this regard and defines disability to include 'the loss or limitation of opportunities to take part in normal life ... due to physical, mental or social factors' ${ }^{89}$ Unfortunately the condition of albinism is accompanied by health issues that adversely affect those living with it, with the result that children with albinism need special attention, care and support. Because they suffer from skin discolouration and visual impairment and are highly prone to contracting cancer and other diseases, they consistently require special health treatment. ${ }^{90}$ Thus, it is evident that the definition in the Act appropriately covers persons with albinism, in general, and children with albinism, in particular. ${ }^{91}$ However, despite the potential of the Act to protect children with albinism, the reality is that the purported protection rarely is applied and seldom materialises. ${ }^{92}$ The result is a dire lack of appropriate education that accommodates the visual disability and special needs of children with albinism. ${ }^{93}$

Clearly, the conditions in the temporary holding shelters do not serve the best interests of children with albinism as they effectively perpetuate human rights violations against them. ${ }^{94}$ For many of the children being housed in a centre is similar to being detained, as these centres lack the necessary facilities to support a life that is free of abuse. ${ }^{95}$ The government, therefore, is urged to take cognisance of the implications of the violation of these children's human rights and to develop sustainable and effective policies that will address these children's social protection, housing needs and access to public spaces, especially because these children have to live away from their natural family environments and homes.

\subsection{The right to education and the paucity of educational resources}

Children with albinism, as are all children, are entitled to live in an environment where all the necessary educational resources are readily available. Article 28 of CRC states that '[a]ll children have the right to a primary education, which should be free'. Young people also should be encouraged to reach the highest level of education of which they are capable. ${ }^{96}$ Article 29 provides that education should optimally 'develop each child's personality, talents and abilities. It should encourage children to respect others' human rights as well as their own and other cultures. ${ }^{97}$ Also, it should 'help them learn to live

\footnotetext{
89 Sec 3 Persons with Disabilities Act 2010.

90 UTSS (n 8).

91 Persons with Disabilities Act 2010.

92 African Children's Committee Report (n 14).

93 As above.

94 UTSS (n 8).

95 As above.

96 RC Sprinthall, GT Schmutte \& L Siros Understanding educational research (1991) 89.

97 As above.
} 
peacefully, protect the environment and respect other people'.$^{98}$ All these goals are achievable if resources are available and sufficient. ${ }^{99}$ Not only is the lack of resources one of the factors that can cause any institution to fail to achieve its goals, but it can also cause stagnation in the academic, health and psychosocial development of children. ${ }^{100}$ The UTSS report indicates that almost all the centres investigated have a shortage of teaching and learning materials and other related facilities and that the children living there suffer because of the scarcity of both human and non-human resources. ${ }^{101}$ Moreover, many of these centres have a shortage of staff and of adequately trained personnel to address the needs of these children. ${ }^{102}$

According to Human Rights Watch insufficient teaching and learning materials, the shortage of classrooms and desks and overcrowded classrooms in these centres are alarming realities. ${ }^{103}$ Article 17 of CRC stipulates that children are entitled to information and materials that are of social and cultural benefit and that are derived from a diversity of community, national and international sources. Access to such information and materials is essential for children with albinism who need to realise their right to participate fully in education through, amongst others, cultural and artistic activities. $^{104}$ States are encouraged

to ensure that children are provided with the widest possible access to different media and thus to information and materials related to their own and other cultures in a language that they understand, including sign language and Braille, and by permitting exceptions to copyright laws in order to ensure the availability of printed materials in alternative formats. ${ }^{105}$

In so doing care must be taken to protect and preserve children's learning processes. ${ }^{106}$ However, it has been reported that there are neither enough teaching materials nor enough teachers to help the children in the temporary holding centres. ${ }^{107}$ Reports also reveal that there are no support materials such as video magnifiers, large-print textbooks, audio tapes, large-print copies of board notes, and the use of computers to supplement reading and to enable the children to stay abreast of technological developments. ${ }^{108}$

\footnotetext{
98 As above.

99 As above.

100 As above.

101 UTSS (n 8).

102 As above.

103 Human Rights Watch (n 16).

104 As above.

105 As above.

106 As above.

107 UTSS (n 8).

108 As above.
} 


\subsection{The right to rest, leisure and recreational activities}

Leisure, rest, play and recreation are essential to the health and wellbeing of children and promote the development of creativity, selfconfidence, imagination, self-efficacy, emotional strength and physical, social and cognitive skills. Playing and leisure contribute to all aspects of learning as 'they are a form of participation in everyday life and are of intrinsic value to the child in terms of the enjoyment and pleasure they afford'. ${ }^{109}$ Research highlights that 'playing is also central to children's spontaneous drive for development and that it plays a significant role in the development of the brain, particularly in the early years'. ${ }^{110}$ Leisure, rest, play and recreation 'facilitate children's capacities to negotiate, regain emotional balance, resolve conflicts and make decisions'. ${ }^{111}$ Through engaging in leisure, play and recreation, children learn by doing, experimenting with new ideas and exploring and experiencing the world around them and, in so doing, they learn to understand and construct their social and cultural position within the world. ${ }^{112}$

As early as in the 1950s the international community acknowledged the importance of a child being able to play and enjoy recreation as evidenced by the Declaration of the Rights of the Child of $1959 .^{113}$ Article 7 of the Declaration states that '[t]he child shall have full opportunity for play and recreation [and that] society and the public authorities shall endeavour to promote the enjoyment of this right'. CRC further strengthens this statement and explicitly states that state parties should 'recognise the right of the child to rest and leisure, to engage in play and recreational activities appropriate to the age of the child, and to participate freely in cultural life and the arts'.114 The right to leisure is also provided for in the African Children's Charter. ${ }^{115}$ The recognition of the value of leisure, play and recreation in a child's life is recognised in the Tanzanian Law of the Child Act. ${ }^{116}$

According to the UN Committee on the Rights of the Child ${ }^{117}$ there are particular groups of children that face difficulties, particularly in relation to the enjoyment and conditions of equality of their rights as defined in article 31 . Such groups include children with disabilities, girls, poor children, children belonging to minorities and indigenous

109 UNESCO Education for the twenty-first century: Issues and prospects (1998).

110 IPA World 'Children's right to play and the environment' Discussion paper prepared by the International Play Association: Promoting the Child's Right to Play for the UN Committee on the Rights of the Child Day of General Discussion, 2016 Children's Rights and the Environment, http://ipaworld.org/wpcontent/uploads/ 2016/05/IPA-Play-Environment-Discussion-Paper.pdf (accessed 14 February 2018).

111 As above.

112 As above.

113 Proclaimed by UN General Assembly Resolution 1386(XIV) of 20 November 1959.

114 Art 31.

115 Art 12 African Children's Charter.

$116 \operatorname{Sec} 8(1)(\mathrm{g})$.

117 General Comment 17 on the right of the child to rest, leisure, play, recreational activities, cultural life and the arts (art 31). 
children. ${ }^{118}$ It is undeniable that environments that encourage leisure, play and recreational opportunities provide conditions for creativity. Opportunities to exercise competence through self-initiated play 'enhance motivation, physical activity and skills development; immersion in cultural life enriches playful interactions; and enough rest ensures that children have the necessary energy and motivation to participate in play and creative engagement' ${ }^{\prime}$.

The conditions of children with albinism that reside in temporary holding shelters in Tanzania clearly are inconsistent with international norms and standards and with Tanzanian legislation. The report by the UTSS categorically states that children in these centres have no room for sports, play, games and any leisure activities as no timetable or schedule indicates such activities. ${ }^{120}$ At the Buhangija centre, for example, no time is allocated for games or sport and no teacher has been employed for this purpose. ${ }^{121}$ In general, there are no structured and organised activities for children with albinism that reside in the shelters. Equally important is 'the need to create time and space for children to engage in spontaneous play, recreation and creativity and to promote societal attitudes that support and encourage such activities'. ${ }^{122}$ The report by Human Rights Watch indicated that there is poor recognition and implementation of the rights to leisure, rest and recreation in the temporary holding shelters. 123

\subsection{The right to psychosocial care and support}

Article 39 of CRC clearly provides that children who experience neglect, exploitation, abuse or other forms of violence should be supported to assist recovery and reintegration. Children who have been exposed to the devastating effects of any conflict and inhumane treatment especially are entitled to emotional, social and psychosocial care. ${ }^{124}$ Many children with albinism have experienced deprivation, abuse and stigmatisation, and many have witnessed atrocities and suffered overwhelming grief even before arriving at the shelters. ${ }^{125}$ Therefore, they need 'appropriate support if they are to grow into capable and compassionate adults and active citizens engaged in their communities'. ${ }^{126}$ The purpose of psychosocial services, psychological

118 As above.

119 A Gopnik et al Children and development: The importance to play (1999), https:// www.mheducation.co.uk/openup/chapters/0335212999.pdf (accessed 17 February 2018).

120 UTSS (n 8).

121 As above.

122 IPA World (n 110).

123 Human Rights Watch (n 16).

124 G) Duncan \& GJ Brooks 'Family poverty, welfare reform, and child development' (2000) 17 Child Development 188.

125 African Children's Committee Report (n14).

126 As above. 
first aid and professional self-care is to help reduce the stress caused by major life events that children or families have had to face, including experiences of significant ill-treatment. ${ }^{127}$ Psychosocial support is the best process for children in the aftermath of a disaster, as it 'promotes effective coping strategies to mitigate the impact of the disaster as well as any associated bereavement and secondary stressors'. ${ }^{128}$ Child care centres thus are expected to offer guidance to traumatised children and to impact their knowledge of risk factors in order to help them adjust mentally and physically. ${ }^{129}$ If the process is handled sensitively, it will strengthen the ability of the children to feel loved, cared for and protected. ${ }^{130}$

Therefore, it is important to ensure that children with albinism participate meaningfully in issues affecting them. They should be heard and allowed to express their feelings and needs and they should be guided towards appreciating their history and identity. ${ }^{131}$ Moreover, they should be encouraged to set goals and reach their potential. These goals can be achieved only if they have positive, nurturing relationships and connections in their lives, and if they are provided with life skills and safe spaces to live and play. ${ }^{132}$

All services that 'involve children (for example education, health and humanitarian support in emergencies) should be delivered in a way that takes account of their psychosocial well-being ${ }^{\prime}{ }^{133}$ There is no doubt that children with albinism in temporary holding shelters in Tanzania in one way or another have been victims and have survived various atrocities. ${ }^{134}$ Many of them suffer from psychological disturbances for different reasons. ${ }^{135}$ For example, some were abandoned by their parents; others are victims of attacks or have witnessed atrocious attacks or the killing of family members with albinism. ${ }^{136}$ The damage and pain these children experience may last a lifetime if they are not given psychosocial care and support.

Opportunities that entrench the rights of children with albinism under article 39 of CRC can be harnessed as a valuable means to guide these children to externalise their traumatic or difficult life experiences in order to make sense of their past and better cope with their future. The government and other stakeholders aim to help these children recover from the atrocities and other discriminatory acts they

127 DJ Schonfeld \& T Demaria 'Providing psychosocial support to children and families in the aftermath of disasters and crises' (2016) 136 Pediatrics 1.

128 As above.

129 As above.

130 As above.

131 Human Rights Watch (n 16).

132 Office of the Minister for Children in Ireland 'Policy on diversity and equality guidelines for childcare provider' (2006), https://www.dcya.gov.ie/documents/ childcare/diversity_and_equality.pdf (accessed 14 February 2018).

133 As above.

134 UTSS (n 8).

135 UTSS Report (n 12).

136 As above. 
have experienced by placing them in the holding shelters. However, their expectations are not being met, as reports indicate that children with albinism lack quality care, support and love often in hazardous environments. ${ }^{137}$ The lack of trained personnel with professional skills to help children who are traumatised or bereaved and those who suffer loneliness seems to remain a problem. Although laws and policies for their care are in place, implementation issues persist. Similarly, appropriate programmes and activities and resources for the optimal development of these children remain lacking. ${ }^{138}$

A number of provisions in CRC address issues of 'parental guidance, parental responsibilities, separation from parents, family reunification, recovery of maintenance for a child, children deprived of a family environment, illicit transfer and non-return of a child, abuse and neglect, physical and psychological recovery and social reintegration'. ${ }^{139}$ It would appear that these provisions are violated as some families use the centres to 'dump' the 'burden' that they perceive children with albinism to be. ${ }^{140}$ The majority of families visit these centres only occasionally, or not at all. ${ }^{141}$ Many families choose to stay away from their children and leave them to fend for themselves. This neglect serves only to exacerbate the denial of these children's right to psychosocial care and support.

\subsection{Freedom from cruel, degrading and inhuman punishment or treatment}

Article 37 of CRC provides that '[n]o one is allowed to punish children in a cruel or harmful way'. This provision means that even in a case where a child breaks the law he or she should not be treated cruelly. In terms of discipline the Convention does not specify what forms of punishment parents or guardians should use. However, any form of discipline involving violence is unacceptable. It is, however, the duty of states parties to CRC to 'take effective legislative, administrative, judicial or other measures to prevent child from being subjected to torture or cruel, inhuman or degrading treatment or punishment' ${ }^{142}$ As such, there are non-violent and effective ways to discipline children - ways that are appropriate to the children's level of development and that take their best interests into consideration. In most countries laws already define what forms of punishment are considered excessive or abusive. CRC gives each government the space to review and enact its own laws that are in line with the Convention. Tanzania's Law of the Child Act attempts to cover the demand and to protect children from

137 As above.

138 UNICEF/UTSS (n 18).

139 Arts 5, 9, 10, 11, 18(1) \& (2), 19-21, 25, 27(4) \& 39.

140 UTSS (n 8).

141 As above.

142 Art 16(1) CRC. 
all forms of violence, which include beatings that cause harm as contained in the definition of child abuse. ${ }^{143}$

Nevertheless, children with albinism continue to experience cruel treatment and degrading punishment in the temporary holding shelters, including corporal punishment. Corporal punishment is defined as 'any punishment in which physical force is used and is intended to cause some degree of pain or discomfort, however light ${ }^{\prime}{ }^{144}$ It includes slapping or hitting a child with a belt, cane or the hand; shaking, kicking, or pinching; pulling its hair or throwing a child; forcing a child to stay in an undignified or uncomfortable position; scaring a child; burning a child; or compelling excessive physical exercise as a form of discipline. The UTSS report exposed the violation of children's rights in the centres as evidence was found that the children were subjected to corporal punishment and other inhumane treatment. ${ }^{145}$ According to the report children complained about corporal punishment which was prevalent in almost all these centres. ${ }^{146}$ The report indicated that children complained of severe and random beatings for no apparent reason. ${ }^{147}$ This practice clearly is a violation of children's rights and an offence under article 37 of CRC. In some instances teachers and care givers were reported to have punished children by making them stand in the sun to suffer sunburn. 148

Mental and emotional torture also occurs as it was reported that some children were terrified by the threat that they would be returned to their villages to be killed. ${ }^{149}$ Shelter leaders in the Mugeza centre particularly were accused of using this form of abuse. ${ }^{150}$ This threat was used to force the children to do whatever the leaders ordered them to do, regardless of whether the act violated their rights or not. ${ }^{151}$ Such acts of violence, accompanied by corporal punishment, harm these children physically and psychologically and endanger their health. Article 37 of CRC, article 12 of the Tanzanian Constitution, section 13 of the Law of the Child Act and sections 4, 5 and 6 of the Persons with Disabilities Act strongly prohibit such actions.

143 Sec 3 Law of the Child Act of 2009.

144 CRC Committee General Comment 8 para 22, http://tb.ohchr.org/default.aspx? Symbol=CRC/C/GC/8 (accessed 18 February 2018).

145 UTSS (n 8).

146 As above.

147 As above.

148 UNICEF/UTSS Report (n 18).

149 As above.

150 As above.

151 As above. 


\section{Conclusion}

Many children with albinism in Tanzania have been forced to abandon their homes and flee for their lives to seek refuge in temporary holding shelters. However, it is clear from the foregoing discussion that the atrocious reality of continued abuse, marginalisation and denial of their human rights tend to continue at these centres where they hoped to find safety and sustenance. It is our view that the Tanzanian government should take cognisance of the legal framework it has adopted as its basic obligation to work towards the elimination of all forms of violence against children, and specifically children with albinism who reside in temporary holding shelters. The government is duty-bound to investigate the discrimination, stigmatisation, abuse and violence that children with albinism face on a daily basis and take significant steps towards improving the standard of living of these children. These steps can be taken by developing strategies for the implementation of the Law of the Child Act, the UN Convention on the Rights of the Child and other relevant national and international laws.

These strategies could include the training of personnel to provide social and emotional services to children with albinism and by equipping them with knowledge about the use of activities and tools that will support and encourage these children to live healthy and fulfilled lives. They also could include taking measures to remove the barriers that prevent these children from having an effective education. More professional people from the social welfare department should be employed to render services to children with albinism. Moreover, the infrastructure at these centres should be improved and there should be regular monitoring and evaluation visits by knowledgeable officials to ensure that the holding shelters function effectively as rescue centres for children. Finally, but importantly, public education programmes regarding children with albinism should be established and strategies developed to allow these children to reunite with their families on a regular basis. These actions would go a long way towards minimising, if not eradicating, violations of the human rights of children with albinism in Tanzania, generally, and in temporary holding shelters, in particular. 